\title{
KEEFEKTIFAN METODE SQ3R TERHADAP KEMAMPUAN MEMBACA PEMAHAMAN PESERTA DIDIK KELAS IV SD NEGERI KARANGLO
}

\author{
Amalia Nurul Azizah \\ STKIP Darussalam Cilacap \\ Email: amalianurulazizah22@gmail.com
}

\begin{abstract}
Abstrak
Penelitian ini bertujuan untuk mengetahui keefektifan metode SQ3R terhadap kemampuan membaca pemahaman peserta didik kelas IV SD Negeri Karanglo. Jenis penelitian ini adalah True Experimental Design dengan desain penelitian yang digunakan yaitu Pretest-Posttest Control Group Design. Teknik pengumpulan data penelitian berupa tes dan angket. Hasil penelitian menunjukkan bahwa kemampuan membaca pemahaman dengan metode SQ3R lebih tinggi daripada kemampuan membaca pemahaman dengan metode diskusi bagi peserta didik kelas IV SD Negeri Karanglo. Hal tersebut dibuktikan dari hasil $t$-test angket dengan taraf signifikansi $95 \%(0,05)$ diperoleh t hitung $(2,575)>$ t tabel $(2,037)$ serta hasil t-test hasil belajar dengan taraf signifikansi $95 \%(0,05)$ diperoleh $\mathrm{t}$ hitung $(2,963)>\mathrm{t}$ tabel $(2,037)$. Berdasarkan nilai $\mathrm{t}$ hitung tersebut, dapat disimpulkan bahwa metode SQ3R lebih efektif dibandingkan dengan metode diskusi.
\end{abstract}

Kata kunci: metode SQ3R, membaca pemahaman, sekolah dasar

\begin{abstract}
This study aims to determine the effectiveness of the SQ3R method on the ability to read comprehension grade IV students at Karanglo Primary School. The type of this research is True Experimental design with the research design used is PretestPosttest Control Group Design. While the research procedure used is using a research model from expert Sugiyono. Research data collection techniques in the form of tests and questionnaires. The results showed that the ability to read comprehension with the SQ3R method was higher than the ability to read comprehension with discussion methods for grade IV students in Karanglo Primary School. This was evidenced from the results of the questionnaire t-test with a significance level of 95\% (0.05) obtained $t$ arithmetic (2.575) > $t$ table (2.037) and the results of t-test learning outcomes with a significance level of 95\% (0.05) obtained $t$ arithmetic (2.963) > $t$ table (2.037). based on the $t$ value, it can be concluded that the SQ3R method is more effective than the discussion method.
\end{abstract}

Keywords: SQ3R method, reading comprehension, primary school 


\section{Pendahuluan}

Penelitian ini dilatar belakangi oleh beberapa faktor. Diantaranya yaitu derasnya arus informasi yang harus diserap melalui media tulisan menyebabkan penguasaan keterampilan membaca semakin terasa diperlukan oleh peserta didik.

Meskipun informasi dapat ditemukan dari media lain seperti televisi dan radio, namun peran membaca tidak dapat digantikan oleh sumber belajar lain sepenuhnya. Membaca tetap memegang peranan penting dalam kehidupan sehari-hari karena tidak semua informasi bisa didapatkan dari media televisi dan radio. Sedangkan yang terjadi di lingkungan masyarakat sesungguhnya, budaya membaca khususnya membaca buku semakin berkurang. Oleh sebab itu, keterampilan membaca peserta didik harus diperhatikan dengan baik.

Keterampilan membaca pemahaman juga harus dimiliki peserta didik dalam kegiatan pembelajaran. Semua mata pelajaran membutuhkan keterampilan membaca pemahaman untuk memperoleh informasi dan ilmu pengetahuan dari mata pelajaran tersebut. Keterampilan membaca pemahaman yang rendah akan mempengaruhi hasil belajar peserta memiliki keterampilan atau kompetensi didik dalam suatu mata pelajaran. yang dibutuhkan untuk meningkatkan
Sehingga untuk memperoleh hasil belajar yang tinggi, peserta didik harus memiliki keterampilan membaca pemahaman yang baik. Sebagaimana yang disampaikan dalam UU No.20 Tahun 2003 tentang Sistem Pendidikan Nasional bahwa "salah satu prinsip penyelenggaraan pendidikan adalah pendidikan diselenggarakan dengan mengembangkan budaya membaca, menulis dan berhitung bagi segenap warga masyarakat". Artinya, keterampilan membaca merupakan suatu keterampilan yang harus dikuasai oleh setiap peserta didik mulai dari jenjang sekolah dasar. Rendahnya keterampilan membaca pemahaman peserta didik dapat disebabkan oleh beberapa faktor, yaitu faktor yang berasal dari diri peserta didik maupun dari luar diri peserta didik. Oleh karena itu, perlu adanya perhatian dari pendidik untuk mengetahui keterampilan membaca pemahaman peserta didik. Dalam hal ini pendidik mempunyai peranan penting untuk membimbing peserta didik dalam meningkatkan keterampilan membaca pemahaman.

Membimbing peserta didik dalam meningkatkan keterampilan membaca pemahaman bukan merupakan pekerjaan yang mudah. Pendidik perlu Dasar, Vol.5, No.1, Februari 2021 
keterampilan membaca pemahaman memahami isi teks bacaan tersebut. peserta didiknya. Keterampilan atau Pendidik yang berperan sebagai kompetensi pendidik meliputi suatu fasilitator di kelas, diharapkan mampu cara/metode maupun penggunaan media mengakomodasi kebutuhan tersebut pembelajaran yang digunakan oleh sesuai karakteristik dan tingkat pendidik dalam meningkatkan perkembangan peserta didik untuk keterampilan membaca peserta didik. menunjang keberhasilan belajar. Hal ini dimaksudkan untuk mencapai tujuan agar peserta didik dapat lebih mudah mendapatkan informasi maupun ilmu pengetahuan dari berbagai sumber. Pada pelaksanaan

kegiatan pembelajaran membaca pemahaman, umumnya pendidik masih menggunakan metode pembelajaran tradisional dan belum bervariasi.

Berdasarkan observasi yang dilakukan di kelas IV SD Negeri Karanglo tahun pelajaran 2019/2020 dengan melakukan wawancara kepada wali kelas, Ibu Intan Wiyadi Putri diperoleh informasi bahwa dalam kelas masih ada peserta didik yang belum lancar membaca sehingga kegiatan membaca pemahaman peserta didik belum menunjukan hasil yang maksimal. Pembelajaran yang biasa pendidik lakukan yaitu hanya dengan menggunakan ceramah. Hal tersebut membuat peserta didik kurang aktif dalam kegiatan pembelajaran khususnya membaca, karena kegiatan yang dilakukan hanya terpaku pada satu aturan yaitu mengerjakan soal tanpa dengan judul "Keefektifan Metode

Salah satu metode yang secara spesifik dirancang untuk dapat memahami teks dalam proses membaca pemahaman adalah dengan menggunakan metode pembelajaran Survey, Question, Read, Recite, dan Review (SQ3R) yang dikembangkan oleh Francis P. Robinson dari Ohio University (Sagala, 2014:59). Penggunaan metode SQ3R dalam proses membaca di SD Negeri Karanglo belum sepenuhnya dilakukan oleh pendidik. Pendidik pada umumnya belum mengetahui pengaruh penggunaan model SQ3R ini terhadap keterampilan atau kemampuan membaca pemahaman peserta didik. Penerapan metode SQ3R yang dibelajarkan pada periode awal kelas tinggi diharapkan dapat membuat peserta didik lebih siap mengaktualisasi diri dalam berbagai bidang sehingga mereka mampu menjawab tantangan globalisasi.

Berdasarkan hasil pemikiran diatas, peneliti melakukan penelitian 49 | Keefektifan Motode SQ3R Terhadap Kemampuan Membaca Pemahaman Peserta Didik.... 
SQ3R Terhadap Kemampuan Membaca Pemahaman Peserta Didik Kelas IV SD Negeri Karanglo"

Berdasarkan latar belakang masalah, maka dapat diidentifikasi berbagai masalah, diantaranya sebagai berikut:

1. Budaya membaca yang semakin berkurang.

2. Pembelajaran membaca kurang mendapat perhatian, baik dari pendidik maupun peserta didik.

3. Pendidik belum menggunakan cara/ metode pembelajaran yang bervariasi.

4. Kemampuan membaca pemahaman peserta didik belum mencapai hasil yang maksimal.

Berdasarkan identifikasi masalah di atas, peneliti membatasi permasalahan pada nomor 3 dan 4 yaitu pendidik belum menggunakan cara/ metode pembelajaran yang bervariasi dan kemampuan membaca pemahaman peserta didik belum mencapai hasil yang maksimal.

Adapun tujuan penelitian ini adalah untuk mengetahui bagaimana penerapan dan keefektifan metode SQ3R dalam kegiatan pembelajaran membaca pemahaman peserta didik kelas IV SD Negeri Karanglo tahun pelajaran 2019/2020.

Manfaat penelitian ini diharapkan dapat memperkaya kajian teoritis tentang keefektifan penggunaan metode SQ3R terhadap kemampuan membaca pemahaman peserta didik, sebagai bahan memperkaya ilmu pengetahuan dan sebagai acuan untuk melakukan penelitian selanjutnya. Selain itu diharapkan dapat menambah wawasan penelitian tentang hal-hal yang berkaitan dengan pembelajaran. Manfaat selanjutnya diharapkan dapat meningkatkan keterampilan membaca pemahaman peserta didik sehingga mampu menumbuhkan minat membaca bagi peserta didik dan dapat memberikan informasi tentang metode yang tepat untuk digunakan dalam meningkatkan keterampilan membaca pemahaman bagi peserta didik SD.

\section{Metode Penelitian}

Penelitian ini dilaksanakan di kelas IV SD Negeri Karanglo Kecamatan Cilongok, Kabupaten Banyumas, Kode Pos 53162. Sekolah tersebut beralamat di Jalan Pramuka RT 01 RW 02. Penelitian ini dilakukan pada Semester Ganjil Tahun Pelajaran 2019/2020.

Desain penelitian yang digunakan dalam penelitian ini adalah PretestPosttest Control Group Design yang merupakan salah satu metode desain True Experimental Design. Populasi 
dalam penelitian yang dilakukan ini yaitu seluruh peserta didik SD Negeri Karanglo Tahun Pelajaran 2019/2020. Sedangkan sampel dalam penelitian yang dilakukan peneliti adalah peserta didik kelas IV SD Negeri Karanglo Tahun Pelajaran 2019/2020.

Teknik pengambilan sampel yang digunakan dalam penelitian ini yaitu menggunakan Cluster Sampling yang merupakan bagian dari teknik Probability Sampling. Probability sampling adalah teknik pengambilan sampel yang memberikan peluang yang sama bagi setiap unsur atau anggota populasi untuk dipilih menjadi anggota sampel. Sedangkan teknik Cluster Sampling digunakan untuk menentukan sampel bila obyek yang akan diteliti atau sumber data sangat luas. (Sugiyono,2009:83).
Teknik pengumpulan data yang peneliti lakukan adalah sebagai berikut:

1. Tes

Bentuk tes yang peneliti gunakan untuk mengukur hasil belajar peserta didik kelas IV SD Negeri Karanglo berupa lembar soal Multiple Choice atau pilihan ganda yang terdiri dari 20 butir soal dengan 4 pilihan jawaban. Tes ini digunakan untuk mengukur kemampuan kognitif peserta didik dalam membaca pemahaman pada muatan pembelajaran Bahasa Indonesia khususnya pada KD 3.9. Tes ini diberikan kepada peserta didik sebelum dan sesudah adanya perlakuan (eksperimen metode SQ3R).

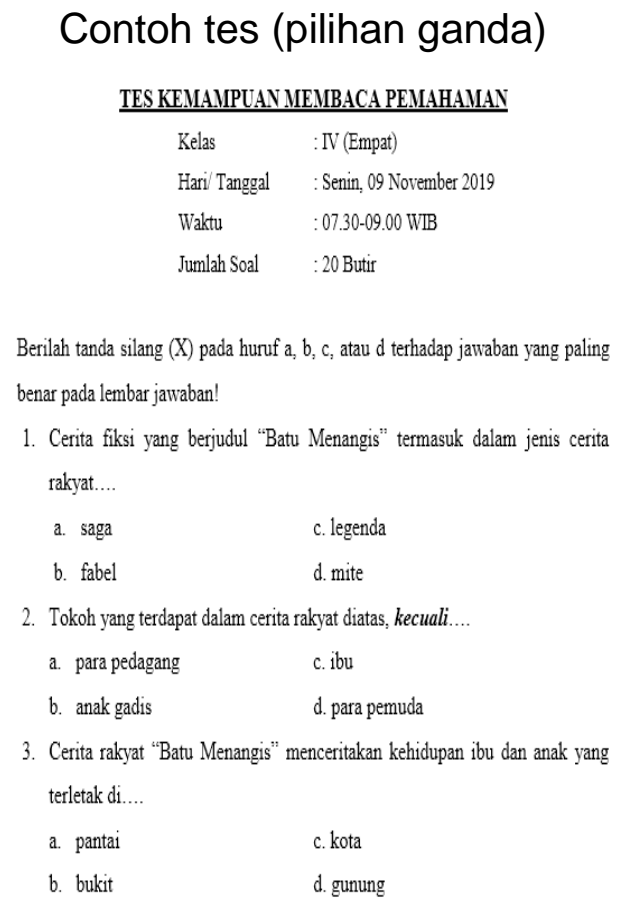

51 | Keefektifan Motode SQ3R Terhadap Kemampuan Membaca Pemahaman Peserta Didik..... 
2. Angket

digunakan untuk memperoleh data

Angket merupakan teknik mengenai keefektifan metode SQ3R pengambilan data yang dilakukan dalam meningkatkan kemampuan dengan cara memberi seperangkat membaca pemahaman peserta didik. pernyataan tertulis kepada Angket akan diberikan sesudah responden untuk dijawabnya dilaksanakannya perlakuan (Sugiyono 2009:142). Dalam (eksperimen metode SQ3R. penelitian yang dilakukan ini, angket

Contoh angket



\begin{tabular}{|l|l|l|l|l|l|}
\hline No & Aspek yang Dinilai & SS & S & TS & STS \\
\hline 1. & $\begin{array}{l}\text { Saya dapat mengidentifikasi latar sebuah } \\
\text { cerita rakyat dengan tepat }\end{array}$ & & & \\
\hline 2. & $\begin{array}{l}\text { Saya tidak dapat mengidentifikasi latar } \\
\text { sebuah cerita rakyat dengan tepat }\end{array}$ & & & & \\
\hline 3. & Saya selalu mampu mengidentifikasi tokoh & & & & \\
\hline
\end{tabular}

3. Observasi dan Wawancara

Observasi dan wawancara dilakukan untuk mendapatkan data awal mengenai permasalahan yang ada di SD Negeri Karanglo khususnya pada peserta didik kelas IV.
Wawancara yang dilakukan adalah dengan melakukan tanya jawab antara peneliti kepada wali kelas IV SD Negeri Karanglo Tahun Pelajaran 2019/2020. 


\section{Contoh Wawancara}

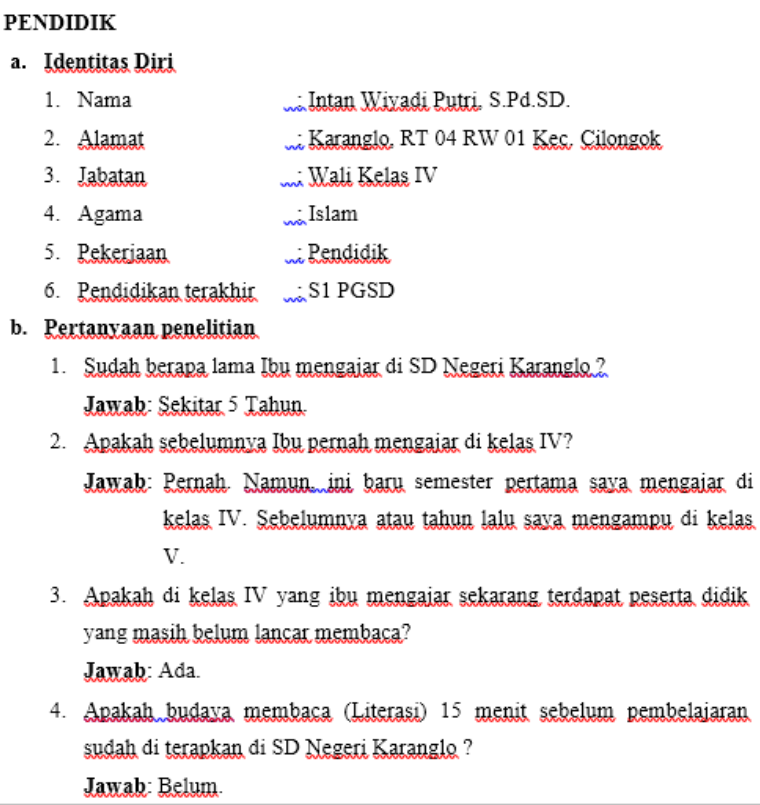

4. Dokumentasi

Dokumentasi yang digunakan dalam penelitian ini berupa hasil wawancara bersama kepala sekolah dan guru kelas IV SD Negeri Karanglo, hasil tes dan angket peserta didik, daftar nilai peserta didik, serta berupa foto pelaksanaan pembelajaran Bahasa Indonesia peserta didik dalam menggunakan metode SQ3R.

Teknik Uji Validitas dan Reliabilitas Instrumen Penilaian kognitif yang digunakan dalam penelitian yang dilakukan yaitu berupa tes objektif terdiri dari 20 butir soal yang berupa pilihan ganda dengan empat pilihan jawaban. Sebelum digunakan dalam penelitian, instrument penilaian kognitif diujicobakan terlebih dahulu untuk menguji validitas dan reliabilitasnya.

Pada penelitian ini, perhitungan koofisien korelasinya dilakukan dengan koefisien korelasi biserial titik atau point biserial Arikunto (2010: 326) menyebutkan bahwa point biserial corellation atau korelasi point biserial digunakan apabila untuk mengetahui korelasi antara dua variabel yaitu variabel kontinyu sedangkan yang lain variabel diskrit murni. Rumus perhitungan koefisien korelasi biserial yang dapat digunakan adalah sebagai berikut :

$$
\gamma_{\mathrm{pbi}}=\frac{\mathrm{M}_{\mathrm{p}}-\mathrm{M}_{\mathrm{t}}}{\mathrm{S}_{\mathrm{t}}} \sqrt{\frac{\mathrm{p}}{\mathrm{q}}}
$$

Keterangan :

$\mathrm{Ypbi}=$ Koefisien korelasi biserial

$\mathrm{Mp}=$ Rerata skor dari subjek yang menjawab benar bagi item 


$$
\begin{array}{ll} 
& \text { yang dicari validitasnya } \\
\mathrm{Mt}= & \text { Rerata skor total } \\
\mathrm{St} & =\text { Standar deviasi dari skor total } \\
\mathrm{p} \quad= & \text { Proporsi peserta didik yang } \\
& \text { menjawab benar } \\
\mathrm{q} \quad \begin{array}{l}
\text { Proporsi peserta didik } \\
\text { yang menjawab salah }
\end{array} \\
\mathrm{q=1}-\mathrm{p}
\end{array}
$$

(Arikunto, S. 2013: 79)

Pada penelitian ini, metode yang digunakan untuk uji reliabilitas yaitu dengan menggunakan metode Kuder dan Richardson (KR-20). Untuk perhitungan koefisien reliabilitas dapat dilakukan dengan rumus:

$\mathrm{r} 11=\frac{N(\Sigma X Y)-(\Sigma X)(\Sigma Y)}{\sqrt{\left[\left(N \Sigma X^{2}-(\Sigma X)^{2}\right)\left(N \Sigma Y^{2}-(\Sigma Y)^{2}\right)\right]}}$

Keterangan :

$r_{11}=$ reliabilitas tes secara keseluruhan

$\mathrm{p}=$ proporsi subyek yang menjawab item dengan benar

$\mathrm{q}=$ proporsi subyek yang menjawab item dengan salah

$\mathrm{Q}=1-\mathrm{p}$

$\sum p q=$ jumlah hasil perkalian antara $p$ dan $\mathrm{q}$

$\mathrm{n} \quad$ = banyaknya item

$\mathrm{S}=$ standar deviasi dari tes (standar devisi adalah akar varians)

Instrumen penilaian psikomor keterampilan membaca pemahaman berupa angket. Jenis angket yang digunakan adalah angket langsung yang terdiri dari 20 butir pernyataan dan menyediakan 4 alternatif jawaban. Sebelum digunakan untuk mengambil data penelitian instrument tersebut diujicobakan terlebih dahulu untuk mengetahui kualitas item angket.

Untuk menghitung validitas butir soal angket dicari dengan menghitung indeks korelasi antara $\mathrm{X}$ dan $\mathrm{Y}$ yang dapat dilakukan dengan rumus product moment sebagai berikut :

$r_{x y}=\left[\frac{n}{n-1}\right]\left[\frac{\mathrm{S}_{\mathrm{t}}-\sum \mathrm{pq}}{\mathrm{S}_{t}^{2}}\right]$

Keterangan :

$r_{x y}=$ koefisien korelasi antara variabel $X$ dan $Y$

$X=$ skor butir item nomor tertentu

$\mathrm{Y}=$ skor total

$\mathrm{N}$ = jumlah subyek.

(Suharsimi Arikunto, 2018: 87)

Pengujian signifikansi korelasi dilakukan dengan membandingakan antara korelasi hitung $(r X Y)$ dengan $r$ pada tabel ( $r$ tabel). Bila $r X Y>r$ tabel maka dapat disimpulkan bahwa $X$ dan $Y$ mempunyai korelasi positif secara signifikan.

Perhitungan koefisien reliabilitas menggunakan metode Rulon yaitu dengan menghitung selisih skor pada kedua belahan. Rumus untuk menghitung koefisien reliabilitas adalah sebagai berikut: 


$$
r_{11}=1-\frac{s_{d}{ }^{2}}{s_{t}{ }^{2}}
$$

Keterangan:

$$
\begin{array}{ll}
\mathbf{r}_{11} & - \text { Kocfisien reliabilitas } \\
S_{d}{ }^{2} & - \text { Varians beda } \\
S_{d}{ }^{2} & -\frac{\sum d^{2}-\frac{\left(\sum d_{1}{ }^{2}\right.}{N}}{N} \\
S_{t}{ }^{2} & - \text { Varians total } \\
S_{t}{ }^{2} & -\frac{\sum x_{t}{ }^{2}-\frac{\left(\sum x_{\mathrm{t}}\right)^{2}}{N}}{N}
\end{array}
$$$$
\text { (Purwanto, 2009: 167-168) }
$$

Analisis data yang dilakukan peneliti yaitu menggunakan bantuan program komputer SPSS Versi 16.0. diantaranya menggunakan uji normalitas, uji homogenitas, uji $t$ paired samples test, dan uji $t$ independent samples test. Data yang dianalisis adalah data hasil belajar dan angket (post test).

Teknik analisis data yang digunakan dalam penelitian ini yaitu menggunakan teknik statistik deskriptif. "Statistik deskriptif adalah statistik yang digunakan untuk menganalisis data dengan cara mendeskripsikan atau menggambarkan data yang telah terkumpul sebagaimana adanya tanpa bermaksud membuat kesimpulan yang berlaku secara umum atau generalisasi" (Sugiyono 2009:147) .

Hipotesis yang diajukan dalam penelitian ini adalah sebagai berikut:

$\mathrm{Ha}_{\mathrm{a}}$ : Metode SQ3R Efektif Terhadap Kemampuan Membaca Pemahaman Peserta Didik
Kelas IV SD Negeri Karanglo tahun Pelajaran 2019/2020.

$\mathrm{H}_{0}$ : Metode SQ3R Kurang Efektif

Terhadap Kemampuan

Membaca Pemahaman

Peserta Didik Kelas IV SD

Negeri Karanglo tahun

Pelajaran 2019/2020.

\section{Hasil dan Pembahasan}

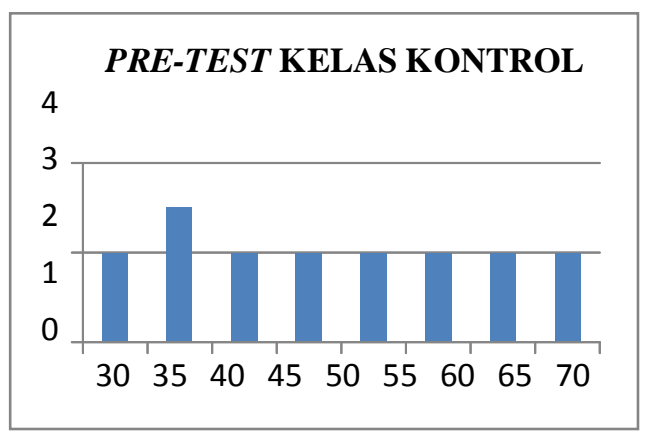

Berdasarkan data tersebut dapat disimpulkan bahwa untuk pretest hasil belajar kelas kontrol sebanyak 15 peserta didik (88\%) belum mencapai KKM, karena untuk KKM pembelajaran bahasa indonesia kelas IV di SD Negeri Karanglo yaitu 69, maka kemampuan membaca pemahaman cerita fiksi pada sekolah tersebut perlu ditingkatkan lagi.

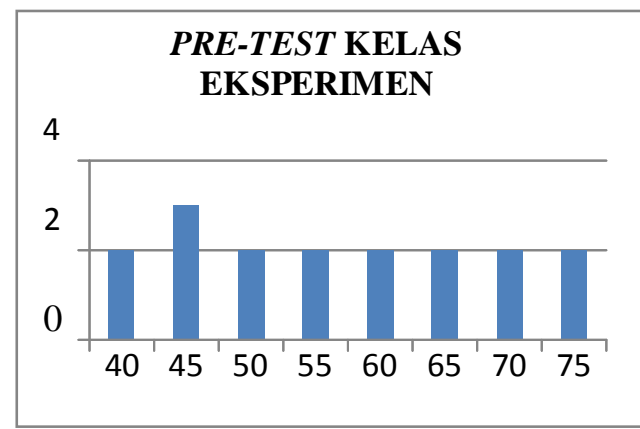

Berdasarkan data tersebut terdapat peserta didik yang belum

55 | Keefektifan Motode SQ3R Terhadap Kemampuan Membaca Pemahaman Peserta Didik..... 
mencapai KKM yaitu sebanyak 13 peserta didik (76,47 \%). Dari penjabaran tersebut dapat disimpulkan bahwa kelas eksperimen masih dikatakan lebih baik perolehan hasil belajar membaca pemahaman cerita fiksi dibandingkan kelas kontrol. Perbedaan rata-rata untuk pretest hasil belajar kelompok kontrol dan eksperimen juga tidak begitu tinggi, hanya selisih 6 angka lebih besar kelompok eksperimen.

POST-TEST KELAS KONTROL

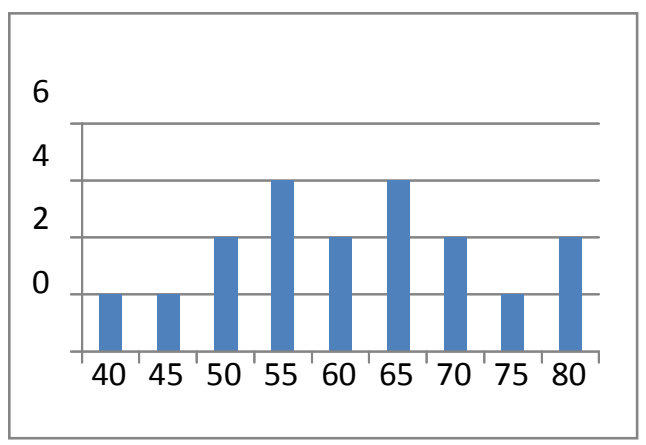

Rata-rata atau mean nilai posttest hasil belajar kelompok kontrol tersebut adalah 62, dan mengalami kenaikan rata-rata dari nilai pretest sebelumnya yaitu 51 . Kenaikan tersebut sebanyak 11 angka.

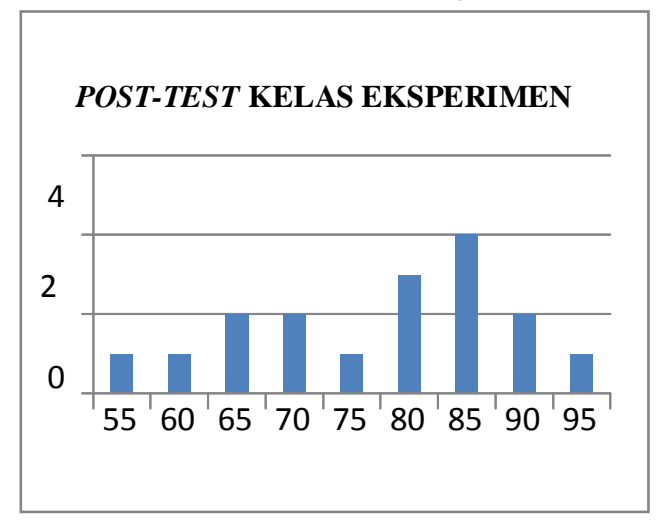

Hasil perolehan nilai posttest tertinggi untuk kelas eksperimen adalah 95 dan nilai terendah 55. Ratarata atau mean kelas eksperimen yaitu 75. Beberapa anak juga mengalami kenaikan nilai dengan tuntas KKM, dari yang awalnya hanya 4 peserta didik $(23,52 \%)$ menjadi 11 peserta didik (65\%). Perolehan rata-rata naik sangat tinggi dari 57 menjadi 75.

Hasil penelitian menunjukan bahwa Metode SQ3R berpengaruhterhadap kemampuan membaca pemahaman peserta didik kelas IV SD Negeri Karanglo Tahun Pelajaran 2019/2020. Hal ini ditunjukan melalui pemerolehan hasil pengolahan data statistik menggunakan program SPSS versi 16.0. Berdasarkan hasil perhitungannya diperoleh uji $t$ test Angket kemampuan membaca pemahaman cerita fiksi sebesar 2,575 sedangkan nilai $t$ tabel pada taraf signifikan $\quad 95 \% \quad(0,05)$ menunjukkan angka sebesar 2,037. Jadi nilai $t$ hitung $>t$ tabel, maka penerapan Metode SQ3R memberikan pengaruh positif tehadap kemampuan membaca pemahaman cerita fiksi peserta didik. Sedangkan untuk nilai $t$ test hasil belajar membaca pemahaman cerita fiksi menunjukkan angka sebesar 2,963 dan nilai $t$ tabel 
pada taraf signifikansi $(0,05)$ menunjukkan angka sebesar 2,037. Jadi $t$ hitung $>$ dari $t$ tabel, maka dapat disimpulkan bahwa penggunaan Metode SQ3R dalam kegiatan pembelajaran berpengaruh terhadap hasil belajar. Melalui hitungan statistik menggunakan uji $t$ yang diolah menggunakan SPSS tersebut secara keseluruhan menyatakan bahwa Metode SQ3R memberikan pengaruh terhadap kemampuan dan hasil belajar membaca pemahaman cerita fiksi, metode tersebut memberikan perbedaan pengaruh yang positif.

Slameto (2010:

54-

72) menyebutkan tentang:

Faktor yang mempengaruhi hasil belajar dari luar atau eksternal, yaitu:

1. Keluarga (cara orang tua mendidik, relasi antar anggota keluarga, suasana rumah, keadaan ekonomi keluarga, pengertian orang tua, latar belakang kebudayaan)

2. Sekolah yaitu metode mengajar, kurikulum, relasi guru dengan peserta didik, relasi peserta didik dengan peserta didik, disiplin sekolah, alat pelajaran, waktu sekolah, standar pelajaran di atas ukuran, keadaan gedung, metode belajar, dan tugas rumah. didik dalam masyarakat, teman bergaul, bentuk kehidupan masyarakat).

Berdasarkan pendapat Slameto, faktor yang mempengaruhi tingkat keberhasilan dalam belajar disekolah salah satunya yaitu penggunaan metode pembelajaran. Dalam hal ini peneliti menggunakan metode pembelajaran berupa metode SQ3R. Namun dalam kegiatan pembelajaran pasti terdapat peserta didik yang mengalami penurunan nilai atau pun naik. Tetapi dalam penelitian ini khususnya kelas eksperimen semuanya mengalami peningkatan meskipun belum sepenuhnya tuntas nilai KKM.

Keberhasilan dalam belajar yang telah dicapai pada penelitian ini khususnya kemampuan dan hasil belajar membaca pemahaman cerita fiksi membuktikan bahwa Metode SQ3R memberikan sebuah perubahan terhadap kemampuan dan hasil belajar membaca pemahaman peserta didik dan meninggalkan perubahan positif seperti yang diharapkan oleh pendidik.

3. Masyarakat (kegiatan peserta

57 | Keefektifan Motode SQ3R Terhadap Kemampuan Membaca Pemahaman Peserta Didik..... 


\section{Kesimpulan}

Langkah-langkah metode SQ3R pada peserta didik kelas IV SD Negeri Karanglo Tahun Pelajaran 2019/2020 dilakukan dengan 5 tahap, yaitu: Survey, mengidentifikasi teks bacaanseperti judul, pengarang, dan unsur-unsur instrinsik cerita fiksi. Question, menyusun daftar pertanyaan berdasarkan teks bacaan atau berdasarkan hasil survei yang dilakukan. Read, membaca teks bacaan cerita fiksi dengan cermat dan teliti, sembari mencari jawaban dari pertanyaan yang telah dibuat. Recite, menuliskan jawaban dari pertanyaan yang telah dibuat. Review, memeriksa kembali jawaban yang telah dituliskan.

Pembahasan diatas menyimpulkan bahwa metode SQ3R berpengaruh terhadap kemampuan membaca pemahaman cerita fiksi pada Peserta Didik Kelas IV SD Negeri Karanglo. Hasil perhitungan ini dilihat dari perolehaan melalui uji $t$ hitung angket kemampuan membaca pemahaman cerita fiksi yaitu sebesar 2,575 sedangkan nilai $t$ tabel pada taraf signifikan 95\% $\quad(0,05) \quad$ menunjukan angka sebesar 2,037. Jadi metode SQ3R berpengaruh kemampuan membaca pemahaman cerita fiksi dimana $\mathrm{t}$ hitung $>\mathrm{t}$ tabel $(2,575>2,037)$. Hasil belajar membaca pemahaman cerita fiksi juga ikut meningkat yaitu melalui uji $t$ diperoleh nilai $t$ hitung sebesar 2,963, sedangkan nilai $t$ tabel pada taraf signifikan $95 \%$ $(0,05)$ menunjukan angka sebesar 2,037. Jadi, metode SQ3R berpengaruh terhadap hasil belajar membaca pemahaman cerita fiksi dimana $t$ hitung $>t$ tabel $(2,963>$ $2,037)$.

Berdasarkan simpulan di atas maka "Metode SQ3R Efektif Terhadap Kemampuan Membaca Pemahaman Cerita Fiksi Peserta Didik Kelas IV SD Negeri Karanglo Tahun Pelajaran 2019/2020". Hal tersebut membuktikan bahwa hasil penelitian sesuai denganhipotesis $(\mathrm{Ha})$ yang diajukan peneliti dalam kegiatan penelitian ini. Adapun saran yang dapat diberikan peneliti yaitu pada kegiatan pembelajaran sebaiknya menerapkan variasi metode agar peserta didik lebih bersemangat dalam belajar sehingga kemampuan membaca pemahamannya meningkat. Salah satunya yaitu bisa dengan menerapkan metode SQ3R. 


\section{Daftar Pustaka}

Arikunto, S. (2018). Dasar-Dasar Evaluasi Pendidikan. Jakarta: Bumi Aksara.

Djamarah, S.B. dan Zain, A. (2002). Strategi Belajar Mengajar. Jakarta: PT Rineka Cipta.

Komalasari, K. (2010). Pembelajaran Kontekstual: Konsep Dan Aplikasi. Bandung: Refika Aditama.

Ngalimun dan Alfulaila, N. (2014). Pembelajaran Keterampilan Berbahasa Indonesia. Yogyakarta: Aswaja Pressindo.

Ngalimun. (2014). Strategi Dan Model Pembelajaran. Yogyakarta: Aswaja Pressindo.

Ngalimun. Fauzani, M. dan Salabi, A. (2016). Strategi dan Model Pembelajaran. Yogyakarta: Aswaja Pressindo.

Nursalim. (2018). IImu Pendidikan Suatu Pendekatan Teoretis dan Praktis. Depok: Rajawali Pers.

Purwanto. (2009). Evaluasi Hasil Belajar. Yogyakarta: Pustaka Pelajar.

Rahim, F. (2018). Pengajaran Membaca Di Sekolah Dasar. Jakarta: Bumi Aksara.

Rahmadani, S. (2018). Pengaruh Metode Pembelajaran SQ3R Terhadap Hasil Belajar Bahasa Indonesia Kelas V MI N Sei Agul Kecamatan Medan Denai. Dilihat Pada Tanggal 06 April 2019 Pukul 07.02 WIB.

Sagala, S. (2014) Konsep dan Makna Pembelpelajaran Untuk Membantu Memecahkan Problematika Belajar dan Mengajar. Bandung: Alfabeta.

Slameto. (2010). Belajar dan Faktor- Faktor yang mempengaruhinya. Jakarta: PT Rineka Cipta

Somadayo, S. (2011). Strategi dan Teknik Pembelajaran Membaca. Yogyakarta: Graha IImu.

Suandi, I N. Sudiana, I N. dan Nurjaya I G. (2018). Keterampilan Berbahasa Indonesia Berorientasi Integrasi Nasional dan Harmoni Sosial. Depok: Rajawali Pers.

Sudaryono. (2018). Metodologi Penelitian. Depok: Rajawali Pers.

Sugiyono. (2009). Metode Penelitian Kuantitatif, Kualitatif dan $R \& D$. Bandung: Alfabeta.

Sunhaji. (2015). Strategi Pembelajaran. Yogyakarta: Pustaka Senja.

Tarigan, H.G. (2015). Membaca Sebagai Suatu Keterampilan Berbahasa.

59 | Keefektifan Motode SQ3R Terhadap Kemampuan Membaca Pemahaman Peserta Didik..... 
Amalia Nurul Azizah

Bandung: Angkasa.

UU No. 20 Tahun 2003 Tentang Sistem Pendidikan Nasional 